\title{
Discussion on the Cultivation of Comprehensive Ability of College Students by the Electronic Design Contest
}

\author{
Wang Changtao* \\ Information and Control Engineering Academy, \\ Shenyang Jianzhu University \\ Shen Yang, China \\ e-mail: arnold0110@sina.com \\ * Corresponding Author
}

Cheng Juan

Shenyang Jianzhu University

Shenyang, China

Han Zhonghua

Shenyang Jianzhu University

Shenyang, China

Zhao Haoxuan

Shenyang Jianzhu University

Shenyang, China

\begin{abstract}
Objective: The electronic design contest for national college students not only plays a more important role in the teaching reform of electronic information specialty in Colleges and universities, but also plays an important role in the cultivation of innovative talents and a guiding role in the innovation education. Methods: To carry out electronic design contest, improving the quality of education has a pivotal role, it can promote the transformation of college teachers teaching ideas, scientific research ability, but also promote the reform of the professional curriculum system, theory and practice teaching. Results: In this paper, we have discussed the function of the college students' comprehensive ability in the electronic design competition, and combined with the training method and the effect of the Shenyang Jianzhu University. Conclusion: The contest improve and cultivate students' ability to access data, self-learning ability, analysis and problem solving skills.
\end{abstract}

Keyword-Electronic Design Contest; comprehensive ability training; teaching quality; practical ability; special training mode

\author{
Wang Xin \\ School of Information \& Control Engineering \\ Shenyang Jianzhu University \\ Shenyang, China
}

\author{
KAN Fenglong \\ School of Information \& Control Engineering \\ Shenyang Jianzhu University \\ Shenyang, China \\ Zhang Dongwei \\ School of Information \& Control Engineering \\ Shenyang Jianzhu University \\ Shenyang, China \\ Wang Bin \\ Northeastern University at Qinhuangdao \\ Qinhuangdao, China
}

\section{BACKGROUND AND THE SIGNIFICANCE OF ELECTRONIC DESIGN COMPETITION}

The National College Students' innovative experiment project is the first project in the end of 2007. The purpose is to explore and establish the teaching mode which is the core of the problem and the project. It advocates the innovative experimental reform, which is the main part of undergraduate students.

National Undergraduate Electronic Design Competition, has become one of the largest extracurricular scientific and technological activities for the National College students. The purpose of the paper is to focus on the teaching practice, focus on the principles, promoting the construction of electronic information specialty and course, and guiding the college students to develop their innovative ability and cooperation spirit. Practice has proved that the national college students electronic design contest for the implementation of quality education in Colleges and universities, the cultivation of students' practical ability and innovation ability has been greatly promoted. At the same time, the event has become a symbol of the examination and assessment of College Students' professional core application ability and 
innovation ability, and it has a certain guiding role on how to cultivate and improve students' innovation ability and corresponding professional construction, curriculum construction and teaching reform.

\section{PROBLEMS OF ELECTRONIC INFORMATION MAJOR STUDENTS}

Through the National Undergraduate Electronic Design Contest of the guidance and organization of the competition, the current electronic information professional in the process of education and teaching mode in the process of training for the core application ability and innovation ability, the following problems exist:

Deficiency of ability to analyze problems: In the process of training and competition, the students cannot solve a complete and reasonable solution, which reflects the theory of daily classroom teaching is not solid, and cannot contact the actual theory, lacking effective practice.

Theoretical contact with the practical ability of students in the program design process and system debugging and debugging of the module cannot be applied to the theoretical knowledge of the actual system. This reflects the daily teaching, or heavy theoretical teaching, light experimental practice, theoretical teaching in the concept of the application of the theory, and the experimental results are more comprehensive and comprehensive, less design experiments, professional core competencies can not reflect.

Enthusiastic and superabundant, lacking patience: many students enthusiasm to participate in the registration process for a few games, but to team up in the process of examination and medium-term training many students but take the initiative to give up. This phenomenon reflects the students' rigorous understanding of the scientific research, but also reflects the lack of a similar exercise practice, the lack of understanding of the core application ability.

Lack of practice ability: in pre and post training participating in the process, some of the students showed unreasonable layout of circuit board components, wires to is not standardized, poor weld basic skills, advanced oscilloscope function cannot be skilled in the use of, instrument and equipment in the process of assembling overcautious and not efficient utilization of network resources etc. phenomenon.

\section{ELECTRONIC DESIGN CONTEST FOR STUDENTS OF ELECTRONIC INFORMATION PROFESSIONAL COMPREHENSIVE ABILITY TRAINING}

Through to the construction industry especially the applied research in the field of intelligent buildings, using the technology professional seminars, expert consultation, understand the professional talent demand situation, the actual work of the application of professional knowledge, And the modern construction industry of electronic information engineering undergraduate professional core application requirements. In electronic design contest as a platform, and strive to improve comprehensive ability, students to solve the above shortcomings.

Combined with the characteristics of building class colleges and universities, build can stimulate the construction of the students of electronic information engineering theory to study the enthusiasm of the practice teaching platform with scientific practice, can promote the professional core technology application ability and improve the rate of employment.

Through the introduction of competition mechanism, displayed the students desire for knowledge, and converted into a professional core technology application ability of practice. Competition for a link to theoretical study, experiment, practice, course design, graduation design, the college students' innovation practice teaching links such as organic combine to form a unified whole. To fulfill the requirements of employment before the practical skills, can reduce unit of choose and employ persons pre-service training task.

Abandon the past "The teachers take the initiative to instill, the students passively receiving" type of teaching method. In order to design contest, and the problems in the application in the construction field as the guidance, form discussion, lecture, integrated design, and other forms of teaching to cultivate students' autonomous learning and the ability to think actively. Outstanding personalized training, let the students have the freedom to explore the time and space, encourage students' autonomous learning, to participate in scientific research project training, cultivate their interest in scientific research, so that make their ambition more ambitious.

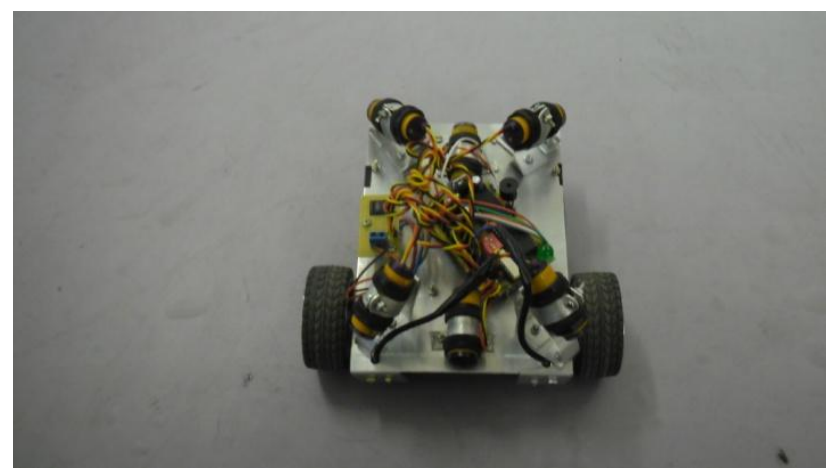

Figure 1. the figure of 2010 entries

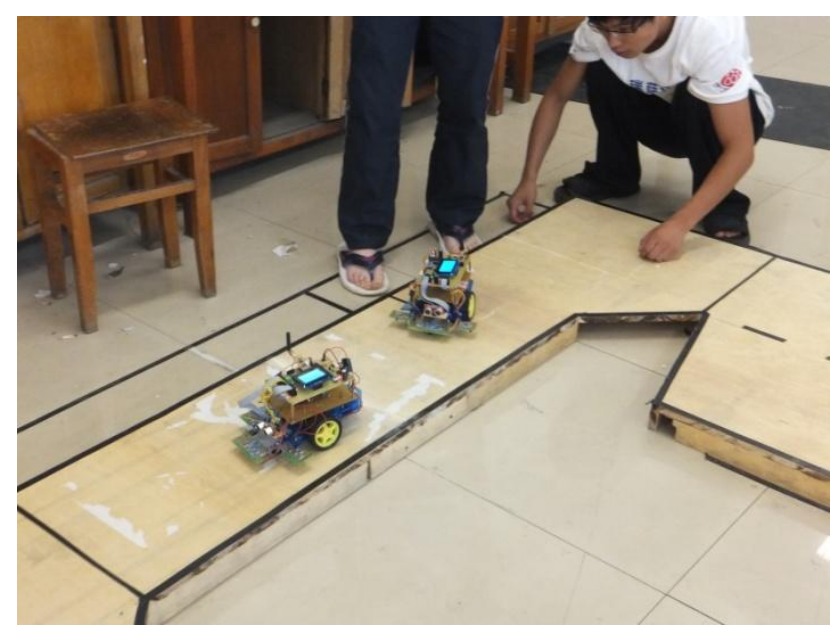

Figure 2. the figure of 2012 entries 


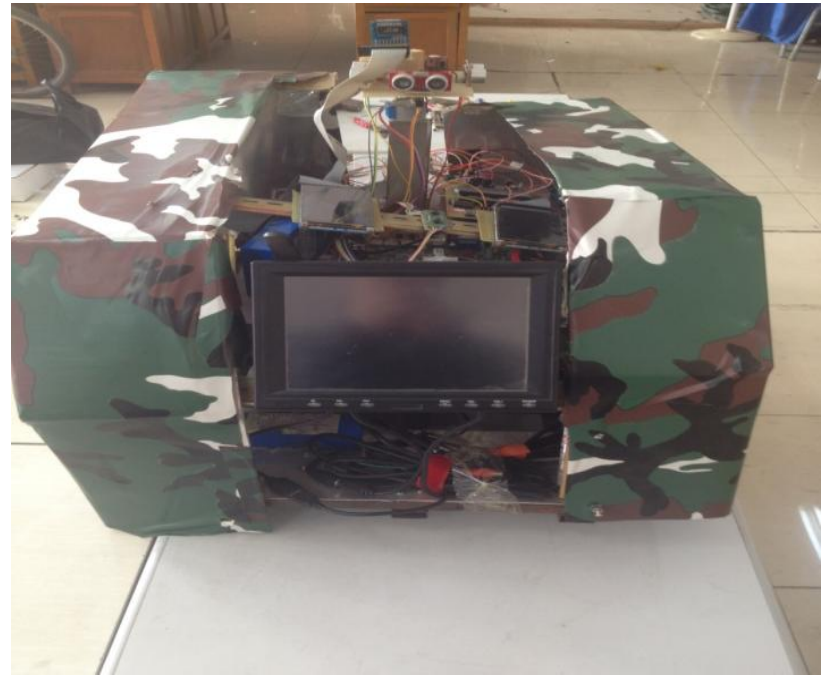

Figure 3. the figure of 2015 entries

Conclusion the national undergraduate electronic design contest training and guidance work, combining with the construction characteristics of electronic information specialty, looking for a variety of competitions in the four years of professional training in the process of combining site, exploring the training hierarchical structure of the competition, optimize the teaching system, research explore the competition mechanism into the implementation of the professional training plan, build a teaching platform to raise the capacity of professional core application technology.

Promote the open laboratory, improve the utilization efficiency of lab equipment. Through different grade professional course learning and the combination of the design competition training plan, update teaching content, mainly including professional experiment, course design, course practice, graduation design, etc., and provide more experimental environment for students, combined with related enterprise, adopt the management method of open mode, in which let the students can do some design of experiment, the experimental equipment can not only make full use of school resources, and can let those students interested in your innovative ideas into reality.

Fig. 1 shows a single function of the car that was made by students in 2010. Fig. 2 shows the student's work in 2012, the functions of the work are increased. Fig. 3 shows the entries of 2015 , the function of the car was continuously increased, and the system of the car became more and more complex.

\section{SPECIAL TRAINING MODE AND EFFECT ANALYSIS OF ELECTRONIC DESIGN CONTEST IN OUR SCHOOL}

The electronic information specialty in our school has carried out the practice teaching mode of "sandwich", and has set up 15 weeks of professional practice, which develop students' practical ability in electronic design by using the theory of the University's teaching and design practice. First of all, students participated in the electronic design contest at school are to complete the six semester of basic courses, professional basic courses and some professional courses in the classroom theory study, and then the sixth semester in the summer of nearly two months of concentrated training, the school opened a dedicated laboratory, the purchase of hardware and software debugging equipment, and assign specific teachers to guide students to complete special training. The simulation of the combination of theory and practice, the combination of young teachers and teachers, in order to achieve the best results. After the practice of training and electronic design competition, students learn the rest of the professional course and complete the graduation design task. From the feedback effect of the students in our college, the mode of this model is to deepen the theoretical knowledge, master the practical skills, to improve the ability of the work and the coordination of the work.

Through the analysis and summary of the national college students electronic design contest and the employment situation of the graduates, it is necessary to understand the technical requirements of the modern construction industry in the electronic and information technology.

Research theory teaching, practice teaching, graduation design, design competition of the integration relationship, the professional core technology application ability of the contribution of the role, determine the key objectives of each link, forming a unified overall training structure, establishing a clear professional core technology application ability training characteristics of teaching system.

Electronic competition is a process of mutual exchange, mutual promotion and mutual learning process of the students in the future work of innovation and training is a great improvement, innovation ability to improve the operation of electronic design contest has a strong role in promoting, but also put forward higher requirements for college students. Students into the team, the practice of the accumulation of experience, are conducive to themselves. Participants to select the appropriate equipment and components, to the end to make a finished product, and not simply on the computer to assemble virtual components. By taking part in the competition, the students' practical innovation ability has been greatly improved. The competition has made the students obtain good theoretical basis and practical ability, especially obtain innovative consciousness and spirit of cooperation. Electronic design competition not only has the section of theoretical analysis, but also has the section of practical ability, which is a comprehensive quality training. In the special competition, the students are trained to meet the needs of many social needs, the implementation of the program to meet the needs of the students, and the students have experienced by the planning, design, manufacturing, commissioning the whole development process. Embodies the students intelligence, the ability to compete, but also reflects the students in selfconfidence, character, perseverance and other non intelligence factors of competition.

Table 1 shows the number of students get scholarships and higher education. 
TABLE I COMPARISON BETWEEN TWO GROUP

\begin{tabular}{|l|l|l|l|}
\hline & $\begin{array}{l}\text { first-class } \\
\text { scholarship }\end{array}$ & $\begin{array}{l}\text { Second- } \\
\text { class } \\
\text { scholarship }\end{array}$ & $\begin{array}{l}\text { Third-class } \\
\text { scholarship }\end{array}$ \\
\hline $\begin{array}{l}\text { Competition } \\
\text { Students }\end{array}$ & 16 & 10 & 4 \\
\hline $\begin{array}{l}\text { Normal } \\
\text { Students }\end{array}$ & 10 & 8 & 12 \\
\hline
\end{tabular}

Take 30 students participated in the electronic competition for example. Table 1 shows the difference between the students participated in the competition and the students who are not participated in. We can see from table 1 that there are 26 students get first-class scholarships, but the number of students who are not participated in the competition is only 10 .It is obvious that the influence of the electronic competition on students is important.

\section{CONCLUSIONS}

As the country's high level of reserve personnel, college students will be the main force for China's future development, will facing a more arduous historical task. It is very important to cultivate students' innovative quality education in the same time, which is required to construct the knowledge structure, ability structure and quality structure of college students. In the two aspects of education and ability cultivation, the cultivation of innovative quality of college students should be the key factor of education and become the basic point of university education. Therefore, we should pay attention to the accumulation of theoretical knowledge, the improvement of practical ability and the cultivation of innovative consciousness, improve and cultivate students' ability to access data, self-learning ability, analysis and problem solving skills, comprehensive design and debugging ability, scientific and technological paper writing ability, unity and cooperation spirit and innovation consciousness, to increase the social competitiveness of students. Through the electronic design competition, we can improve the comprehensive quality of the students themselves.

\section{REFERENCE}

[1] Chen Chaofeng,Guo Shuchao,Cha Daifeng."From the electronic design contest to see the teaching reform of large information,"Journal of jiujiang University,2012,4:pp.120-121.

[2]Wang Dongmei,Zhang Chijian."Research and Discussion on the construction of electronic information specialty in Normal Colleges,'Work \& Study Abroad,2011,22:pp.196-196.

[3]Bai Yun,Cai Wang."Promoting innovative talents cultivation based on the electronic design contest for College Students,"SCIENCE\&TECHNOLOGY INFORMATION,2013 , 4:pp.123-124.

[4]Ma Li,Yang Xiaofeng,Niu Bin."Exploration on the integration mode of the electronic design contest and the experimental teaching,"Experiment Science \&Technology,2013,11(2):pp.141-143.

[5]Wang Xin,Guo Lili,Ma Lina. Cooperative Spectrum Sensing Algorithm Based on Second User Selection and Random Forest Classification[J]. ICIC Express Letters, Part B: Applications,2015, 6(3):845-850.

[6]Song Kehui,Tian Shengwen,Peng Qingwen."Knowledge, ability, quality structure and cultivation of Applied Talents,"Higher Education Research,2012,33(7):pp.94-98.

[7]Li Wenguo,Cui Zhi,Deng Shuguang."Discussion of the electronic design competition for college students innovation ability,"Electric Power Education in China,2012,8:pp.115-116.

[8]Yang Yi,Xu Peng,Peng Xiaofeng."Electronic design competition and practice teaching reform,"RESEARCH AND EXPLORATION IN LABORATORY,2013,32(4):pp.172-175.

[9]Wang Xin, Huang Kuan, Gao Zhijun. The Primary Users' Signals Recognition Algorithm in Cognitive Radio Networks via KPCA and Random Forest[J].ICIC Express Letters,2015, 9(4):1083-1088.

[10]Wei Bin."Quality characteristics of the compound teachers in Colleges and Universities under the mode of compound talents cultivation,”SHANGYE JINGJI,2012,3:pp.94-96.

[11]Zhang Yan,Chen Liang."On the construction of undergraduate science and technology innovation platform in ordinary private colleges,"Journal of HuBei Adult Education Institute,2013,19(1):pp.19-20. 